\title{
Article
}

\section{Surface coupling of methyl radicals for efficient low-temperature oxidative coupling of methane}

\author{
Shihui Zou a,t,\#, Zhinian Li a,†, Qiuyue Zhou a, Yang Pan ${ }^{b}$, Wentao Yuan c, Lei Hea, Shenliang Wang a, \\ Wu Wen ${ }^{\mathrm{b}}$, Juanjuan Liu d, Yong Wang c, Yonghua Du e, Jiuzhong Yang b, Liping Xiao a, \\ Hisayoshi Kobayashi f,\&, Jie Fan a,* \\ a Key Laboratory of Applied Chemistry of Zhejiang Province, Department of Chemistry, Zhejiang University, Hangzhou 310036, Zhejiang, China \\ b National Synchrotron Radiation Laboratory, University of Science and Technology of China, Hefei 230029, Anhui, China \\ c School of Materials Science and Engineering, Zhejiang University, Hangzhou 310027, Zhejiang, China \\ d College of Materials \& Environmental Engineering, Hangzhou Dianzi University, Hangzhou 310036, Zhejiang, China \\ e National Synchrotron Light Source II, Brookhaven National Laboratory Upton NY, 11973, USA \\ ${ }^{\mathrm{f}}$ Emertus Professor of Kyoto Institute of Technology, Matsugasaki, Sakyo-ku, Kyoto 606-8585, Japan
}

\section{A R T I C L E I N F O}

\section{Article history:}

Received 4 January 2021

Accepted 9 January 2021

Available online 5 March 2021

\section{Keywords:}

Oxidative coupling of methane

Bifunctional catalysis

Methyl radicals

Surface coupling

$\mathrm{La}_{2} \mathrm{O}_{3}$

$\mathrm{Na}_{2} \mathrm{WO}_{4} / \mathrm{SiO}_{2}$

\begin{abstract}
A B S T R A C T
Selective coupling of methyl radicals to produce $\mathrm{C}_{2}$ species $\left(\mathrm{C}_{2} \mathrm{H}_{4}\right.$ and $\left.\mathrm{C}_{2} \mathrm{H}_{6}\right)$ is a key challenge for oxidative coupling of methane (OCM). In traditional OCM reaction systems, homogeneous transformation of methyl radicals in $\mathrm{O}_{2}$-containing gases are uncontrollable, resulting in limited $\mathrm{C}_{2}$ selectivity and yield. Herein, we demonstrate that methyl radicals generated by $\mathrm{La}_{2} \mathrm{O}_{3}$ at low reaction temperature can selectively couple on the surface of $5 \mathrm{wt} \% \mathrm{Na}_{2} \mathrm{WO}_{4} / \mathrm{SiO}_{2}$. The controllable surface coupling against overoxidation barely changes the activity of $\mathrm{La}_{2} \mathrm{O}_{3}$ but boosts the $\mathrm{C}_{2}$ selectivity by three times and achieves a $\mathrm{C}_{2}$ yield as high as $10.9 \%$ at bed temperature of only $570{ }^{\circ} \mathrm{C}$. Structure-property studies suggest that $\mathrm{Na}_{2} \mathrm{WO}_{4}$ nanoclusters are the active sites for methyl radical coupling. The strong $\mathrm{CH}_{3}$. affinity of these sites can even endow some methane combustion catalysts with OCM activity. The findings of the surface coupling of methyl radicals open a new direction to develop OCM catalyst. The bifunctional OCM catalyst system, which composes of a methane activation center and $\mathrm{a} \mathrm{CH}_{3}$. coupling center, may deliver promising OCM performance at reaction temperatures below the ignition temperature of $\mathrm{C}_{2} \mathrm{H}_{6}$ and $\mathrm{C}_{2} \mathrm{H}_{4}\left(\sim 600{ }^{\circ} \mathrm{C}\right)$ and is therefore more controllable, safer, and certainly more attractive as an actual process.
\end{abstract}

(C) 2021, Dalian Institute of Chemical Physics, Chinese Academy of Sciences. Published by Elsevier B.V. All rights reserved.

\section{Introduction}

Methane, the main constituent of the abundant natural gas and shale gas, is widely accepted as a promising alternative resource to crude oil [1]. It is of both scientific and strong economic interest to develop processes that would convert methane to higher valued chemicals such as methanol [2], light olefins [3-5] and aromatics [6,7]. Currently, the industrial-scale

\footnotetext{
* Corresponding author. Tel/Fax: +86-571-87952338; E-mail: jfan@zju.edu.cn

\# Corresponding author. E-mail: xueshan199@163.com

\& Corresponding author. E-mail: hisabbit@yahoo.co.jp

† These authors contributed equally to this work.

This work was supported by National Natural Science Foundation of China (92045301, 91845203, 21802122, 21703050) and Key Program of Research and Development of Hefei Science Center, CAS (2018HSC-KPRD002).

DOI: 10.1016/S1872-2067(20)63756-1 | http://www.sciencedirect.com/journal/chinese-journal-of-catalysis | Chin. J. Catal., Vol. 42, No. 7, July 2021
} 
conversion of methane adopts an indirect route which involves the intermediate manufacture of syngas and subsequent conversion to chemicals or fuels via Fischer-Tropsch or hydrogenation processes [8-12]. Although considerable progress has been achieved recently in directly converting syngas into olefins [8-10], the indirect route is energy and capital intensive which limits its widely applications, specifically in the utilization of remote and inconveniently located natural gas fields [13]. As an alternative, increasing attention has been paid to the direct conversion of methane, especially the oxidative coupling of methane (OCM) to $\mathrm{C}_{2}$ hydrocarbons which involves only a small external energy input [14-17].

Since the pioneering work of Keller and Bhasin in the early 1980s [18], hundreds of catalytic materials composed of 68 elements have been investigated for OCM reaction [19]. Due to the high binding energy of $\mathrm{CH}_{3}-\mathrm{H}$ bond (435 kJ mol-1), oxidative coupling of methane generally proceeds at high temperatures $\left(\geq 700{ }^{\circ} \mathrm{C}\right)[20]$. Because the high temperature process requires special materials for construction, high energy consumption and great capital input, the minimum criteria of $\mathrm{C}_{2}$ yield for industrial application is $30 \%$ [21]. It is recognized that at high temperatures OCM follows a heterogeneous-homogeneous mechanism, which consists of a heterogeneous activation of methane at the surface of catalysts to generate methyl radicals $\left(\mathrm{CH}_{3}{ }^{\circ}\right)$ and a subsequent homogeneous coupling of methyl radicals in the gas phase to produce $\mathrm{C}_{2}$ species $\left(\mathrm{C}_{2} \mathrm{H}_{6}\right.$ and $\left.\mathrm{C}_{2} \mathrm{H}_{4}\right)[22,23]$. Because high temperature favors the desorption of methyl radicals into gas phase, the role of the traditional OCM catalysts is limited mainly to the generation of methyl radicals [24]. The uncontrollable homogeneous reaction of methyl radicals in the presence of $\mathrm{O}_{2}$ thermodynamically favors the overoxidation to $\mathrm{CO}_{2}$, resulting in an upper bound of ca. $25 \%-28 \%$ for $\mathrm{C}_{2}$ yield which is economically infeasible for industrial application [25]. In terms of conventional fixed-bed reactor, the possible exceeding of this limit can be obtained only if catalyst plays significant role not only in heterogeneous generation of methyl radicals but also in their subsequent transformations [14]. Unfortunately, there is no such catalyst that has been ever reported to have activity of coupling methyl radicals.

In this work, we demonstrate $5 \mathrm{wt} \% \mathrm{Na}_{2} \mathrm{WO}_{4} / \mathrm{SiO}_{2}$ as the first heterogeneous coupling catalyst for OCM reaction and systematically investigate its structure-property relationship. The activation of methane takes place over a $\mathrm{La}_{2} \mathrm{O}_{3}$ surface at relative low temperatures [26], which allows the coupling of methyl radicals proceed in a controlled manner on the surface of $\mathrm{Na}_{2} \mathrm{WO}_{4} / \mathrm{SiO}_{2}$ catalyst. Such bifunctional OCM reaction system successfully separates methane activation and $\mathrm{C}-\mathrm{C}$ coupling into two different active components. As a result, a $\mathrm{C}_{2}$ yield up to $10.9 \%$ was achieved at bed temperature of $570{ }^{\circ} \mathrm{C}$, which to the best of knowledge is the highest $\mathrm{C}_{2}$ yield ever reported at such a low reaction temperature (Table S1). Low temperature is desirable for the commercialization of OCM [27]. It not only cuts down the energy loss and the cost of reactors, but also overcomes the limited industrial experience with catalytic processes at high temperatures [28].

\section{Experimental}

\subsection{Synthesis of $\mathrm{La}_{2} \mathrm{O}_{3}$ nanorods}

$\mathrm{La}_{2} \mathrm{O}_{3}$ nanorods were synthesized according to the literature procedure [26]. $5 \mathrm{~mL}$ of $25 \% \mathrm{NH}_{3} \cdot \mathrm{H}_{2} \mathrm{O}$ was added dropwise to $250 \mathrm{~mL}$ of $\mathrm{La}\left(\mathrm{NO}_{3}\right)_{3}\left(0.4 \mathrm{~mol} \mathrm{~L}^{-1}\right)$ solution to form a white slurry. After the slurry was vigorously stirred for $12 \mathrm{~h}$, the white precipitate was obtained through centrifugation, and washed twice with water and ethanol. The precipitate was re-dispersed in $125 \mathrm{~mL}$ of distilled water, and then transferred into Teflon-lined autoclave to perform a hydrothermal treatment at $105^{\circ} \mathrm{C}$ for $24 \mathrm{~h}$. The precipitate was separated by centrifugation, washed with ethanol for several times, and dried in vacuum oven at $25^{\circ} \mathrm{C}$ overnight. Finally, the sample was calcined at $800^{\circ} \mathrm{C}$ for $5 \mathrm{~h}$ before use.

\subsection{Synthesis of $\mathrm{Na}_{2} \mathrm{WO}_{4} / \mathrm{SiO}_{2}$}

$\mathrm{Na}_{2} \mathrm{WO}_{4} / \mathrm{SiO}_{2}$ was prepared by a typical impregnation method [29]. Taking $5 \mathrm{wt} \% \mathrm{Na}_{2} \mathrm{WO}_{4} / \mathrm{SiO}_{2}$ for an example, 1.00 $\mathrm{g}$ of silica gel was added into aqueous solution of $\mathrm{Na}_{2} \mathrm{WO}_{4} \cdot 2 \mathrm{H}_{2} \mathrm{O}$ $(0.05 \mathrm{~g})$. The resulting slurry was stirred continuously at $75^{\circ} \mathrm{C}$ until dry and subsequently dried at $85^{\circ} \mathrm{C}$ overnight. Finally, the sample was calcined at $850^{\circ} \mathrm{C}$ for $5 \mathrm{~h}$ before use.

\subsection{Characterization}

High angle annular dark field scanning transmission electron microscopy (HAADF-STEM) images were acquired on a Cs-corrected Titan Chemi-STEM operating at an accelerating voltage of $200 \mathrm{kV}$. Wide-angle X-ray diffraction (WXRD) patterns were recorded on a Rigaku Ultimate IV with $\mathrm{Cu} K_{\alpha}$ radiation at $40 \mathrm{~mA}$ and $40 \mathrm{kV}$. Synchrotron-based VUV photoionization mass spectrometry (SVUV-PIMS) study was carried out at the combustion beamline of the National Synchrotron Radiation Laboratory at Hefei, China. The X-ray absorption fine structure (XAFS) spectra at W L3-edge of the samples were measured at the XAFCA beamline of Singapore Synchrotron Light Source.

\subsection{Catalytic measurement}

The catalytic tests were performed in a quartz fix-bed reactor tube with an inner diameter of $8 \mathrm{~mm}$ under atmospheric pressure. The catalyst bed was placed on quartz wool plug in the constant-temperature zone of furnace. A thermocouple well with an outer diameter of $6 \mathrm{~mm}$ was inserted into the quartz reactor to monitor the bed temperature and to further reduce the free space volume. $\mathrm{CH}_{4}, \mathrm{O}_{2}$, and $\mathrm{N}_{2}$ in a ratio of 3:1:2.6 were cofed into the reactor through mass flow controllers. The total flow rate was $66 \mathrm{~mL} \mathrm{~min}^{-1}$. The products were analyzed by an online gas chromatography equipped with an FID detector and a TCD detector. Molecular sieve 5A column Porapak N column were coupled with TCD to separate $\mathrm{CO}_{2}, \mathrm{CH}_{4}, \mathrm{O}_{2}$ and $\mathrm{N}_{2}$ while aluminum trioxide capillary column was coupled with FID to separate $\mathrm{CO}_{2}$ and hydrocarbon products $\left(\mathrm{CH}_{4}, \mathrm{C}_{2} \mathrm{H}_{4}\right.$, and $\left.\mathrm{C}_{2} \mathrm{H}_{6}\right)$. 
For testing $\mathrm{La}_{2} \mathrm{O}_{3}$ or $\mathrm{Na}_{2} \mathrm{WO}_{4} / \mathrm{SiO}_{2}$ alone, $100 \mathrm{mg}$ of catalyst was loaded. For mixed or layered experiments, $100 \mathrm{mg}$ of $\mathrm{La}_{2} \mathrm{O}_{3}$ and $100 \mathrm{mg}$ of $\mathrm{Na}_{2} \mathrm{WO}_{4} / \mathrm{SiO}_{2}$ were loaded.

\subsection{In situ SVUV-PIMS measurements}

In situ SVUV-PIMS measurements of methyl radicals and other products were performed on the mass spectrometry beamline (BL04B) and the combustion beamline (BL03U) of the National Synchrotron Radiation Laboratory (Hefei, China) [30]. For the test of single component catalyst, $100 \mathrm{mg}$ of the catalyst (10-20 mesh) was loaded. For the test of $\mathrm{La}_{2} \mathrm{O}_{3}-5 \mathrm{NaWSi}$ composite catalyst, $100 \mathrm{mg}$ of $\mathrm{La}_{2} \mathrm{O}_{3}$ and $100 \mathrm{mg}$ of $5 \mathrm{wt} \% \mathrm{Na}_{2} \mathrm{WO}_{4} / \mathrm{SiO}_{2}$ (10-20 mesh) were premixed before loaded into the reactor. $75 \% \mathrm{CH}_{4}$ and $25 \% \mathrm{O}_{2}$ were cofed into the reactor with a total flow rate of $40 \mathrm{~mL} \mathrm{~min}-1$. The OCM reaction was operated at a total pressure of 2 Torr. After the reactions reached steady state at desired temperatures, the composition of the effluent gas was analyzed by the online SVUV-PIMS. A homemade time-of-flight mass spectrometer (TOF-MS) was used to detect the ion signals, which were amplified with a VT120C preamplifier (EG\&G, ORTEC, Oak Ridge, TN) and recorded by a P7888-2 multiscaler (FAST Comtec, Germany).

\subsection{DFT calculations}

DFT calculations were carried out using a plane-wave-based program, Castep [31,32]. The Perdew-Burke-Ernzerhof functional was used together with the ultrasoft-core potentials $[33,34]$. The basis set cutoff energy was set to 330 and $370 \mathrm{eV}$ for geometry optimization and post-energy evaluation. Explicitly considered electrons are $\mathrm{H}: 1 s^{1}, \mathrm{C}: 2 s^{2} 2 p^{2}, 0: 2 s^{2} 2 p^{4}$, Na: $2 s^{2} 2 p^{6} 3 s^{1}$, Si: $3 s^{2} 3 p^{2}$, and W: $5 s^{2} 5 p^{6} 5 d^{4} 6 s^{2}$.

$\left(\mathrm{Na}_{2} \mathrm{WO}_{4}\right)_{4}$ unit cell was used for the slab model without $\mathrm{SiO}_{2}$ support. Lattice constants are $a=b=6.458 \AA, \alpha=\beta=90^{\circ}$, and $\gamma=120^{\circ}$. The vacuum region was taken in the $c$-direction and set to $c=50 \AA$. For the models supported by $\mathrm{SiO}_{2}$, $\mathrm{WO}_{4}$ tetrahedron was coupled to cristobalite (111) surface through a single $\mathrm{W}-\mathrm{O}-\mathrm{Si}$ bond. The models with different $\mathrm{WO}_{4} / \mathrm{SiO}_{2}$ ratio (density) are used to simulate different sized $\mathrm{Na}_{2} \mathrm{WO}_{4}$. Two types of unit cells are employed. "Small model" $\left(\mathrm{Si}_{12} \mathrm{O}_{28} \mathrm{H}_{6} \mathrm{Na}_{2}\left(\mathrm{WO}_{3}\right)_{2}\right)$ corresponds to high coverage of $\mathrm{WO}_{4}$, and the lattice constants were $a=7.040 \AA, b=8.534 \AA, c=30 \AA$ (including vacuum region), $\alpha=\beta=90^{\circ}$, and $\gamma=114.3^{\circ}$. "Large model" $\left(\mathrm{Si}_{48} \mathrm{O}_{112} \mathrm{H}_{30} \mathrm{Na}_{2}\left(\mathrm{WO}_{3}\right)_{2}\right.$ and $\left.\mathrm{Si}_{48} \mathrm{O}_{112} \mathrm{H}_{26} \mathrm{Na}_{6}\left(\mathrm{WO}_{3}\right)_{6}\right)$ corresponding to low coverage of $\mathrm{WO}_{4}$ was built by four times $(2 \times$ 2) extension of small model in $a$ - and $b$-directions ( $a=14.080$ $\AA$, $b=17.069 \AA$ A). All the atomic coordinates were optimized, and the lattice constants were fixed to the original values. $\mathrm{H}$ atoms were used to encapsulate the terminal $\mathrm{O}$ atoms in $\mathrm{SiO}_{2}$ unit. Chemical composition seems changing irregular among models. This is due to the formation mechanism of $\mathrm{W}-\mathrm{O}-\mathrm{Si}$ bonding. The bond is formed between $\mathrm{O}$ atom of $\mathrm{WO}_{4}$ unit and $\mathrm{HO}$ in $\mathrm{Si}(\mathrm{OH})_{4}$ unit. Formation one $\mathrm{W}-\mathrm{O}-\mathrm{Si}$ bond reduces one $\mathrm{OH}$ fragment.

\section{Results and discussion}

\subsection{OCM involving surface coupling of methyl radicals}

$\mathrm{La}_{2} \mathrm{O}_{3}$ nanorod (Figs. S1 and S2), a well-known low-temperature OCM catalyst [26,35,36], was selected as the active component for methane activation. The composite catalyst, denoted as $\mathrm{La}_{2} \mathrm{O}_{3}-5 \mathrm{NaWSi}$, was prepared by physically mixing $\mathrm{La}_{2} \mathrm{O}_{3}$ nanorods with $5 \mathrm{wt} \% \mathrm{Na}_{2} \mathrm{WO}_{4} / \mathrm{SiO}_{2}$ (denoted as $5 \mathrm{NaWSi}$ ) in a mass ratio of 1 . As shown in Fig. 1(b) and Table $\mathrm{S} 2, \mathrm{La}_{2} \mathrm{O}_{3}$ nanorods exhibit considerable $\mathrm{CH}_{4}$ conversion at bed temperature (the temperature is bed temperature if not otherwise specified) of ca. $570{ }^{\circ} \mathrm{C}$ with limited selectivity to $\mathrm{C}_{2}$ hydrocarbons, which is well consistent with the literature results [26]. Interestingly, upon combination with $5 \mathrm{NaWSi}$, the $\mathrm{C}_{2}$ selectivity is boosted from $14.37 \%$ to $33.93 \%$ with the methane conversion remaining almost unchanged ( 31.3\%). $\mathrm{La}_{2} \mathrm{O}_{3}-5 \mathrm{NaWSi}$ composite achieves a single-pass $\mathrm{C}_{2}$ yield of $10.9 \%$ at ca. $570{ }^{\circ} \mathrm{C}$, which to the best of our knowledge is the lowest bed temperature ever reported for $10 \%$ yield of $\mathrm{C}_{2}$ (Table $\mathrm{S} 1$ ). In addition, $\mathrm{La}_{2} \mathrm{O}_{3}-5 \mathrm{NaWSi}$ composite also delivers very good stability in OCM reaction (Fig. 1(c)) during a 50-hour test at $570{ }^{\circ} \mathrm{C}$ and a gas hourly space velocity (GHSV) of $20000 \mathrm{~mL}$ $\mathrm{h}^{-1} \mathrm{gcat}^{-1}$. For both $\mathrm{La}_{2} \mathrm{O}_{3}$ and $\mathrm{La}_{2} \mathrm{O}_{3}-5 \mathrm{NaWSi}$, the $\mathrm{C}_{2} \mathrm{H}_{4} / \mathrm{C}_{2} \mathrm{H}_{6}$ molar ratios increase with increasing temperature (Table S2), likely due to the favored ethane oxidative dehydrogenation to ethylene at high temperatures. Besides, at high $\mathrm{C}_{2}$ selectivity, more $\mathrm{O}_{2}$ can be used for oxidative dehydrogenation of ethane to ethylene. As a result, higher $\mathrm{C}_{2} \mathrm{H}_{4} / \mathrm{C}_{2} \mathrm{H}_{6}$ ratios are obtained. To further verify the effect of $5 \mathrm{NaWSi}$, we investigated the catalytic performances of $\mathrm{La}_{2} \mathrm{O}_{3}$ nanoparticles $\left(\mathrm{La}_{2} \mathrm{O}_{3} \mathrm{NP}\right.$ ) and $\mathrm{La}_{2} \mathrm{O}_{3} \mathrm{NP}-5 \mathrm{NaWSi}$. As shown in Table S3, although the catalytic performances of $\mathrm{La}_{2} \mathrm{O}_{3} \mathrm{NP}$ and $\mathrm{La}_{2} \mathrm{O}_{3} \mathrm{NP}-5 \mathrm{NaWSi}$ are not as good as those of $\mathrm{La}_{2} \mathrm{O}_{3}$ nanorods and $\mathrm{La}_{2} \mathrm{O}_{3}-5 \mathrm{NaWSi}$ (Table S2), the introduction of $5 \mathrm{NaWSi}$ indeed improves the $\mathrm{C}_{2}$ selectivity and yield of $\mathrm{La}_{2} \mathrm{O}_{3} \mathrm{NP}$. Besides, the improvement induced by $5 \mathrm{NaWSi}$ also applies to other $\mathrm{CH}_{4}$-to- $\mathrm{O}_{2}$ ratios (Fig. S3).

It is important to highlight that although $5 \mathrm{NaWSi}$ can significantly enhance the $\mathrm{C}_{2}$ selectivity and yield of $\mathrm{La}_{2} \mathrm{O}_{3}$, itself is inert for OCM reaction at temperatures below $750{ }^{\circ} \mathrm{C}$ (Fig. 1(a) and Table S2). These results lead us to a hypothesis that $5 \mathrm{NaWSi}$ might drive the transformation of methyl radicals from gas phase to catalyst surface and selectively couple them into $\mathrm{C}_{2}$ hydrocarbons. To test this possibility, we employed a validated synchrotron-based vacuum ultraviolet photoionization mass spectrometry (SVUV-PIMS) to detect the intermediate and products in the gas phase [37]. As shown in Fig. S4, when methane and oxygen were fed into the reactor containing $\mathrm{La}_{2} \mathrm{O}_{3}$ at $600{ }^{\circ} \mathrm{C}$, a signal of mass-to-charge ratio $(\mathrm{m} / \mathrm{z})=15$ appeared at a photon energy $\mathrm{h} v=11 \mathrm{eV}$. Considering the ionization energy and $m / z$ ratio, this species can be unambiguously identified to be methyl radicals $\left(\mathrm{CH}_{3}{ }^{\circ}\right)$. In comparison, no methyl radical was detected by SVUV-PIMS for the catalytic reaction with $5 \mathrm{NaWSi}$ as catalyst or without catalyst. These observations provide direct and solid experimental evidence for the formation of methyl radicals during the catalytic OCM reaction and clearly prove that the detected methyl radicals are gener- 

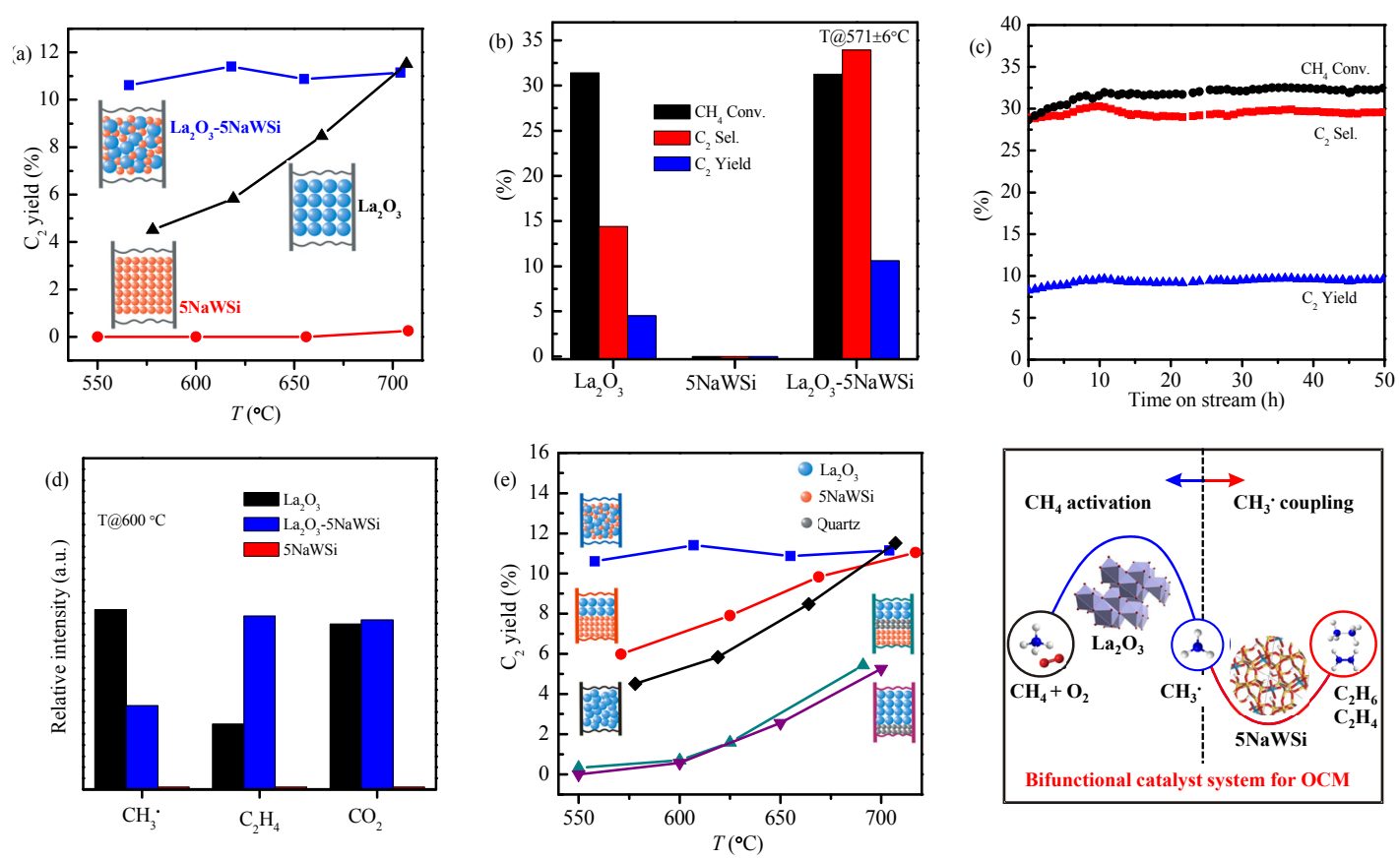

Fig. 1. Catalytic performances of $\mathrm{La}_{2} \mathrm{O}_{3}-5 \mathrm{NaWSi}$ and reference catalysts in OCM reaction. (a) $\mathrm{C}_{2}$ yield as a function of reaction temperature; (b) $\mathrm{CH}_{4}$ conversion, $\mathrm{C}_{2}$ selectivity and $\mathrm{C}_{2}$ yield at $571 \pm 6{ }^{\circ} \mathrm{C}$; (c) A stability test of $\mathrm{La}_{2} \mathrm{O}_{3}-5 \mathrm{NaWSi}$ at $570{ }^{\circ} \mathrm{C}_{1} \mathrm{CH}_{4}: \mathrm{O}_{2}: \mathrm{N}_{2}=3: 1: 2.6$, total gas flow rate $66 \mathrm{~mL}$ min ${ }^{-1}$; (d) Integrated SVUV-PIMS peak intensity of gas-phase methyl radicals, ethylene and $\mathrm{CO}_{2}$ during $\mathrm{OCM}$ reaction catalyzed by various catalysts at $600{ }^{\circ} \mathrm{C}$; (e) $\mathrm{C}_{2}$ yield as a function of reaction temperature over various catalysts (GHSV 20,000 $\mathrm{mL} \mathrm{h}^{-1} \mathrm{gcat}^{-1}$ ); (f) Schematic illustration of reaction process of OCM over $\mathrm{La}_{2} \mathrm{O}_{3}-5 \mathrm{NaWSi}$.

ated by the activation of methane on the $\mathrm{La}_{2} \mathrm{O}_{3}$ catalyst surface. In addition to $\mathrm{CH}_{3} 3^{\circ}$, signals assigned to $\mathrm{C}_{2} \mathrm{H}_{4}(\mathrm{~m} / z=28)$ could also be detected at a photon energy $h v=11 \mathrm{eV}$ while signals assigned to $\mathrm{CO}_{2}(\mathrm{~m} / \mathrm{z}=44)$ could be detected at a photon energy $h v=14.5 \mathrm{eV}$. Integrating the peak intensity of these signals ensures us to quantitatively compare the concentration of each species. As can been seen from Fig. 1(d), upon combination with $5 \mathrm{NaWSi}$, the gas-phase $\mathrm{CH}_{3} \cdot$ generated on $\mathrm{La}_{2} \mathrm{O}_{3}$ reduce, accompanied by an increasing production of $\mathrm{C}_{2} \mathrm{H}_{4}$. These results contradict to the traditional gas-phase coupling mechanism which features proportional $\mathrm{C}_{2}$ products with the gas-phase concentration of $\mathrm{CH}_{3} \cdot[37,38]$ and therefore lead to a conclusion that $\mathrm{CH}_{3} \cdot$ radicals generated by $\mathrm{La}_{2} \mathrm{O}_{3}$ have been coupled on the surface of $\mathrm{Na}_{2} \mathrm{WO}_{4} / \mathrm{SiO}_{2}$ to enhance the $\mathrm{C}_{2}$ hydrocarbon production. It is noteworthy that the increase of $\mathrm{C}_{2}$ yield upon combination with $5 \mathrm{NaWSi}$ is more significant at low temperatures (typically, $<650{ }^{\circ} \mathrm{C}$ ) than at high temperatures (Fig. 1(a)). This is likely due to the facilitated desorption of methyl radicals into gas phase at high temperature which limits the surface coupling of $\mathrm{CH}_{3}{ }^{\bullet}$ over $5 \mathrm{NaWSi}$. Similarly, increasing GHSV leads to a short residence time of $\mathrm{CH}_{3}$. on the catalyst surface. As a result, the improvement of $\mathrm{C}_{2}$ selectivity induced by $5 \mathrm{NaWSi}$ is more significant at low GHSV (Fig. S5).

To further verify the transportation of $\mathrm{CH}_{3}$. from $\mathrm{La}_{2} \mathrm{O}_{3}$ to $5 \mathrm{NaWSi}$, we investigated the influence of integration manner of active components on the catalytic performance. The use of a dual-bed configuration with $5 \mathrm{NaWSi}$ downstream from $\mathrm{La}_{2} \mathrm{O}_{3}$ ( $\mathrm{La}_{2} \mathrm{O}_{3} \| 5 \mathrm{NaWSi}$ ) provides similar $\mathrm{CH}_{4}$ conversion but obviously increased $\mathrm{C}_{2}$ selectivity and yield as compared with $\mathrm{La}_{2} \mathrm{O}_{3}$
(Table S2 and Fig. 1(e)), pointing to the contribution of surface coupling of $\mathrm{CH}_{3}$. over $5 \mathrm{NaWSi}$. Further increasing the proximity of $\mathrm{La}_{2} \mathrm{O}_{3}$ and $5 \mathrm{NaWSi}$ by a mixed-one-bed facilitates the transportation of $\mathrm{CH}_{3}$. from $\mathrm{La}_{2} \mathrm{O}_{3}$ to $5 \mathrm{NaWSi}$ and therefore significantly improves the selective surface coupling of $\mathrm{CH}_{3}$. over $5 \mathrm{NaWSi}$. As a result, $\mathrm{La}_{2} \mathrm{O}_{3}-5 \mathrm{NaWSi}$ (mixed one-bed) shows much higher $\mathrm{C}_{2}$ yield than $\mathrm{La}_{2} \mathrm{O}_{3} \| 5 \mathrm{NaWSi}$ (dual-bed). Besides, the $\mathrm{C}_{2}$ yield could be tuned by varying the relative mass ratio of $\mathrm{La}_{2} \mathrm{O}_{3}$-to-5NaWSi (Fig. S6). Interestingly, the $\mathrm{C}_{2}$ selectivity and yield exhibit volcano-type dependence on the $\mathrm{La}_{2} \mathrm{O}_{3}$-to-5NaWSi ratio with the optimal value achieved at $1: 1$, suggesting there is a balance between the generation and coupling of $\mathrm{CH}_{3}$. This result further supports the above hypothesis that the composite catalyst is bifunctional, and that the reaction involves intermediate transport [9]. On the other hand, once we introduce an intermediate quartz-sand bed to inhibit the transportation of $\mathrm{CH}_{3}$. from $\mathrm{La}_{2} \mathrm{O}_{3}$ to $5 \mathrm{NaWSi}$, no improvement in $\mathrm{C}_{2}$ yield was observed over $\mathrm{La}_{2} \mathrm{O}_{3} \|$ Quartz $\| 5 \mathrm{NaWSi}$ (layer-bed) as compared with $\mathrm{La}_{2} \mathrm{O}_{3} \|$ Quartz (Fig. 1(e)). These results clearly prove that the increase of $\mathrm{C}_{2}$ yield results from the transportation of $\mathrm{CH}_{3}$. radicals from $\mathrm{La}_{2} \mathrm{O}_{3}$ to $5 \mathrm{NaWSi}$ and their subsequent coupling on the surface of $5 \mathrm{NaWSi}$ (Fig. 1(f)). Interestingly, the transportation and surface coupling of $\mathrm{CH}_{3}$. can even take place at a temperature as low as $500{ }^{\circ} \mathrm{C}$ if we replace $\mathrm{La}_{2} \mathrm{O}_{3}$ by $\mathrm{Sm}_{2} \mathrm{O}_{3}$, another excellent low-temperature OCM catalyst [39]. As shown in Fig. S7, the $\mathrm{C}_{2}$ selectivity increases from $6.6 \%$ for $\mathrm{Sm}_{2} \mathrm{O}_{3}$ to $11.8 \%$ for $\mathrm{Sm}_{2} \mathrm{O}_{3} \| 5 \mathrm{NaWSi}$ (dual-bed) at $500{ }^{\circ} \mathrm{C}$. Moreover, due to the thermodynamic driving force [8], the coupling with $5 \mathrm{NaWSi}$ also slightly accelerates the $\mathrm{CH}_{4}$ conver- 
sion over $\mathrm{Sm}_{2} \mathrm{O}_{3}$. As a result, a $\mathrm{C}_{2}$ yield of $2.3 \%$ is achieved at $500^{\circ} \mathrm{C}$.

\subsection{Structure and property of coupling site}

To better understand the origin of coupling property of $5 \mathrm{NaWSi}$ catalyst, a series of reference samples were synthesized by the same method. The difference in $\mathrm{C}_{2}$ yield $\left(\Delta \mathrm{C}_{2}\right.$ yield $)$ between composite catalysts and single $\mathrm{La}_{2} \mathrm{O}_{3}$ catalyst was employed as a descriptor for coupling property. As shown in Fig. 2(a) and Table S4, $5 \mathrm{NaWSi}$ is the only one that can improve the $\mathrm{C}_{2}$ yield of $\mathrm{La}_{2} \mathrm{O}_{3}$ (positive $\Delta \mathrm{C}_{2}$ yield). The distinguished catalytic performance between $5 \mathrm{NaWSi}$ and $\mathrm{Na}_{2} \mathrm{CO}_{3} / \mathrm{SiO}_{2}$ indicates $\mathrm{W}$ is a key component. Substituting $\mathrm{Na}^{+}$by $\mathrm{K}^{+}$or $\mathrm{NH}_{4}^{+}$ disables the coupling of methyl radicals, suggesting $\mathrm{Na}$ is a critical component. Mixing $\mathrm{La}_{2} \mathrm{O}_{3}$ with $\mathrm{Na}_{2} \mathrm{WO}_{4} / \mathrm{Al}_{2} \mathrm{O}_{3}$ decreases the $\mathrm{C}_{2}$ yield, implying $\mathrm{SiO}_{2}$ support is also very important. Pioneer works of $\mathrm{Mn}-\mathrm{Na}_{2} \mathrm{WO}_{4} / \mathrm{SiO}_{2}$ catalysts demonstrated that the presence of $\mathrm{Na}$ induces the low-temperature transformation of amorphous silica into cristobalite [29,40,41]. This result also applies to pure $\mathrm{Na}_{2} \mathrm{WO}_{4} / \mathrm{SiO}_{2}$. As shown in Fig. 2(b), an obvious transformation of amorphous $\mathrm{SiO}_{2}$ into cristobalite is identified in all $\mathrm{Na}^{+}$-containing samples $\left(\mathrm{Na}_{2} \mathrm{CO}_{3} / \mathrm{SiO}_{2}\right.$, $2 \mathrm{NaWSi}, 5 \mathrm{NaWSi}$ and $10 \mathrm{NaWSi}$ ) by XRD. Once $\mathrm{Na}^{+}$is replaced by $\mathrm{NH}_{4}+$, the transformation is inhibited, accompanied by the formation of large $\mathrm{WO}_{3}$ crystalline. Data from literatures $[42,43]$ indicate that there is a strong interaction between cristobalite and $\mathrm{Na}_{2} \mathrm{WO}_{4}$. For $\mathrm{Na}_{2} \mathrm{WO}_{4} / \mathrm{SiO}_{2}$ with different loading amounts, the interaction is different. As shown in Fig. 2(c), the configuration of all $\mathrm{W} \mathrm{L}_{3}$-edge XANES spectra is similar to that of $\mathrm{Na}_{2} \mathrm{WO}_{4}$, suggesting that all $\mathrm{W}$ species have a tetrahedral structure. The white line intensity, however, increases along with the decrease of $\mathrm{Na}_{2} \mathrm{WO}_{4}$ loading, indicating improved $2 p_{3 / 2}$ to $5 d$ transition probability [44] which likely results from the increased interaction between $\mathrm{Na}_{2} \mathrm{WO}_{4}$ and cristobalite. The strongest interaction between $2 \mathrm{NaWSi}$ and cristobalite is also evidenced by a new coordination peak in $R$ space at about $3.4 \AA$ (Fig. 2(d)).

The different interaction between cristobalite and $\mathrm{Na}_{2} \mathrm{WO}_{4}$ eventually changes the dispersion of $\mathrm{Na}_{2} \mathrm{WO}_{4}$. The bright spots
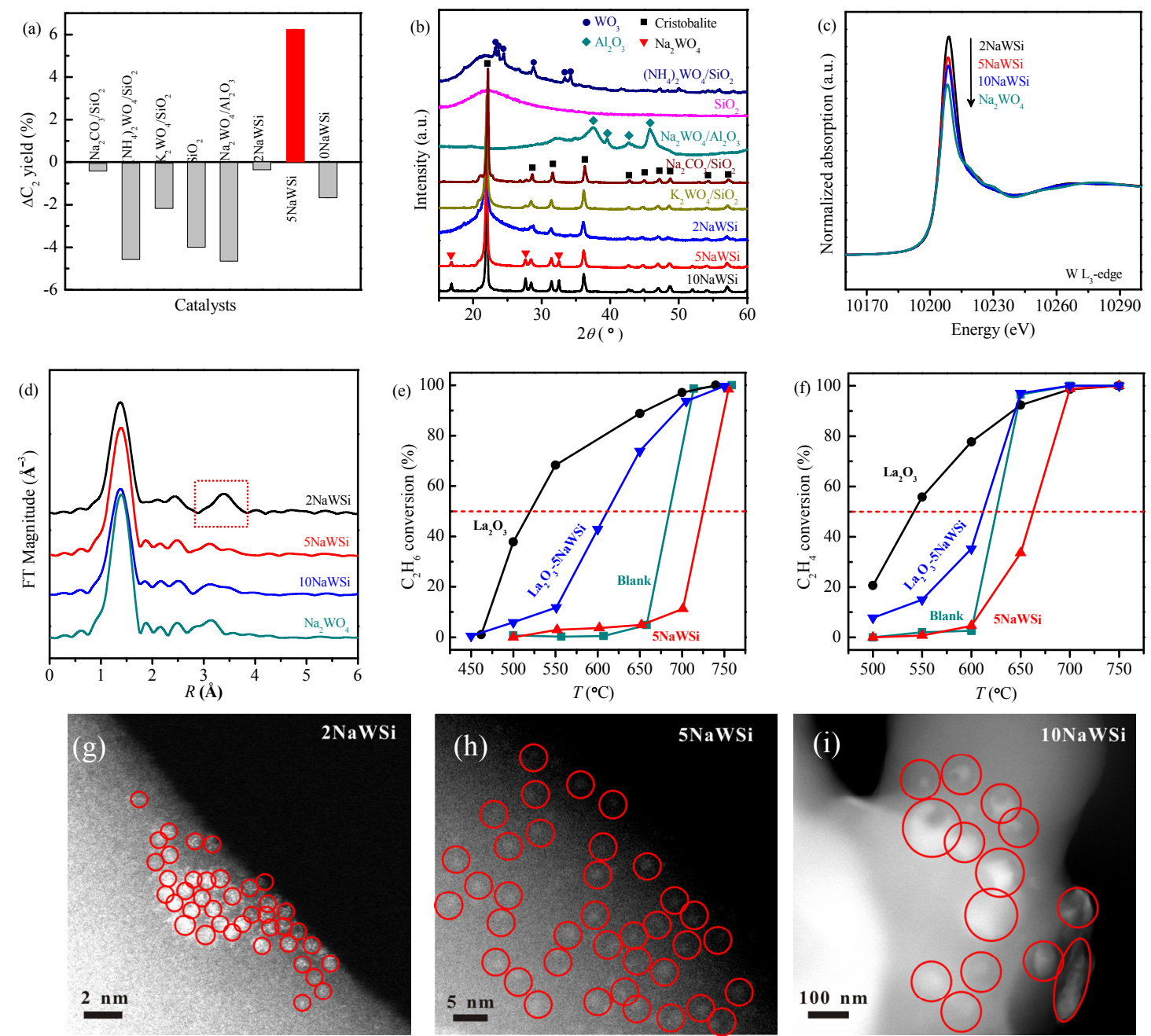

Fig. 2. The structure and property of $5 \mathrm{NaWSi}$. (a) The difference in $\mathrm{C}_{2}$ yield $\left(\Delta \mathrm{C}_{2}\right.$ yield) between composite catalysts and pure $\mathrm{La}_{2} \mathrm{O}_{3}$ at $570{ }^{\circ} \mathrm{C}$; (b) XRD patterns for various catalysts; (c) The $\mathrm{W} \mathrm{L}_{3}$-edge XANES spectra; (d) EXAFS-derived Fourier transforms of $\mathrm{Na}_{2} \mathrm{WO}_{4} / \mathrm{SiO}_{2}$ with different mass loading; Catalytic performance of deep oxidation of (e) ethane and (f) ethylene $\left(\mathrm{C}_{2} \mathrm{H}_{x}: \mathrm{O}_{2}: \mathrm{N}_{2}=1: 6: 5, x=4\right.$ or 6 , gas flow rate $\left.66 \mathrm{~mL} \mathrm{~min}^{-1}\right)$. The red dash lines indicate the ignition temperature at $50 \%$ conversion. HAADF-STEM images of (g) $2 \mathrm{NaWSi}$, (h) $5 \mathrm{NaWSi}$ and (i) $10 \mathrm{NaWSi}$. 
shown in Fig. 2(g) suggests $\mathrm{Na}_{2} \mathrm{WO}_{4}$ is highly dispersed in 2NaWSi with sub-1 nm size (most are atomically dispersed), likely due to the strong interaction between $\mathrm{Na}_{2} \mathrm{WO}_{4}$ and cristobalite. As the loading of $\mathrm{Na}_{2} \mathrm{WO}_{4}$ increases to $5 \mathrm{wt} \%$, the weakened interaction leads to the formation of tungstate clusters, which are identified by HAADF-STEM (Fig. 2(h)). Further increasing the loading to $10 \mathrm{wt} \%, \mathrm{Na}_{2} \mathrm{WO}_{4}$ mainly exist as large particles (> $50 \mathrm{~nm}$, Fig. 2(i)). Correlating these results with catalytic performances, a size effect is identified. $2 \mathrm{~nm}$ sized $\mathrm{Na}_{2} \mathrm{WO}_{4}$ cluster in $5 \mathrm{NaWSi}$ is the optimal catalyst for the coupling of $\mathrm{CH}_{3}$ radicals.

To rationalize the experimental observations, we further performed DFT calculations to determine the coupling property of different sized $\mathrm{Na}_{2} \mathrm{WO}_{4}$ on cristobalite. The structure models were constructed according to the literature reports $[29,43,45]$. Tetrahedral $\left[\mathrm{WO}_{4}\right]$ is grafted onto silica surface by a single $\mathrm{W}-\mathrm{O}-\mathrm{Si}$ bond (removing $\mathrm{OH}$ from $-\mathrm{Si}-\mathrm{OH}$ ), left three terminal $\mathrm{O}$ atoms for the interactions with $\mathrm{CH}_{3}$. The terminal $\mathrm{O}$ atoms in cristobalite (111) surface are saturated by hydrogen atoms. $\mathrm{Na}$ is introduced to maintain the neutrality. The models with different $\mathrm{WO}_{4} / \mathrm{SiO}_{2}$ ratio are used to simulate different sized $\mathrm{Na}_{2} \mathrm{WO}_{4}$ (Fig. S8). $\left(\mathrm{WO}_{3}\right)_{2},\left(\mathrm{WO}_{3}\right)_{6}$, and $\left(\mathrm{WO}_{3}\right)_{8}$ abbreviate $\mathrm{Si}_{48} \mathrm{O}_{112} \mathrm{H}_{30} \mathrm{Na}_{2}\left(\mathrm{WO}_{3}\right)_{2}, \quad \mathrm{Si}_{48} \mathrm{O}_{112} \mathrm{H}_{26} \mathrm{Na}_{6}\left(\mathrm{WO}_{3}\right)_{6}, \quad$ and $\left[\mathrm{Si}_{12} \mathrm{O}_{28} \mathrm{H}_{6} \mathrm{Na}_{2}\left(\mathrm{WO}_{3}\right)_{2}\right]_{4}$, respectively.

The coupling of methyl radicals on catalyst surface consists of three steps, i.e. $\mathrm{CH}_{3} \cdot$ adsorption as the reactant, $\mathrm{CH}_{3}{ }^{\bullet}$ coupling as the transition state, and $\mathrm{C}_{2} \mathrm{H}_{6}$ formation as the product. Theoretically, the adsorbed $\mathrm{CH}_{3}$. can either react with another adsorbed $\mathrm{CH}_{3}$. via a $\mathrm{L}-\mathrm{H}$ mechanism or react with a gas-phase $\mathrm{CH}_{3}$. via an E-R mechanism. Figs. 3(a,b) show the comparison between these two mechanisms over $\left(\mathrm{WO}_{3}\right)_{8}$. Interestingly, the activation energy $\left(E_{\mathrm{a}}\right)$ for E-R mechanism is significantly lower than that for L-H mechanism, indicating the E-R model is thermodynamically more favorable. Similar results are also observed on other models. Therefore, we adopt the E-R mechanism in the following discussion. Interestingly, all the models exhibit considerable amount of adsorption energy ( $\left.E_{\mathrm{ads}}\right)$ of $\mathrm{CH}_{3}$. radicals, which enable them to capture $\mathrm{CH}_{3}$. radicals from gas phase (Figs. 3(c,d)). According to the literature[38], overoxidation reactions (initiated by $\mathrm{CH}_{3} \cdot+\mathrm{O}_{2}$ reaction) in the gas phase make the major contribution to the formation of $\mathrm{CO}$ and $\mathrm{CO}_{2}$ in the OCM reaction. Reducing the concentration of $\mathrm{CH}_{3}$. in gas phase by $\mathrm{Na}_{2} \mathrm{WO}_{4} / \mathrm{SiO}_{2}$ (Fig. 1(d)) might therefore significantly reduce the possibility of $\mathrm{CH}_{3}$. oxidation in gas phase and improve the $\mathrm{C}_{2}$ selectivity. On the other hand, according to the classic Sabatier principle[46], a too strong binding with reactants is also not ideal. It leads to large activation energy, excessive blocking of surface sites, and therefore low catalytic activity. As shown in Figs. 3(c) and S9, the binding between $\mathrm{CH}_{3}$. radicals and $\mathrm{Na}_{2} \mathrm{WO}_{4}(111)$ surface ( $E_{\text {ads }}$ as high as $399 \mathrm{~kJ} \mathrm{~mol}^{-1}$ ) is too strong to allow the coupling of $\mathrm{CH}_{3} \cdot$ radicals. The activation energy $\left(E_{\mathrm{a}}\right)$ is as high as $356 \mathrm{~kJ} \mathrm{~mol}^{-1}$. Grafting $\mathrm{WO}_{4}$ on cristobalite (111) surface remarkably reduces the activation energy by destabilize the reactant. Among the models with different density of $\mathrm{WO}_{4}, E_{\mathrm{a}}$ decreases from 132, 142, to $56 \mathrm{~kJ}$ $\mathrm{mol}^{-1}$ for $\left(\mathrm{WO}_{3}\right)_{2}$, $\left(\mathrm{WO}_{3}\right)_{6}$, and $\left(\mathrm{WO}_{3}\right)_{8}$ and then increases to 356 $\mathrm{kJ} \mathrm{mol}{ }^{-1}$ for $\mathrm{Na}_{2} \mathrm{WO}_{4}(111)$ surface. This trend on one hand sug- gests the coupling property of $\mathrm{Na}_{2} \mathrm{WO}_{4}$ is strongly affected by the $\mathrm{SiO}_{2}$ support, on the other hand, confirms the experimental observation that moderate concentration of $\mathrm{Na}_{2} \mathrm{WO}_{4}$ unit per $\mathrm{SiO}_{2}$ area is optimal (Fig. 2(a)). It is important to highlight that the relative energy of TS in E-R process over $\left(\mathrm{WO}_{3}\right)_{8}$ is negative (lower than gas phase $\mathrm{CH}_{3} \cdot$ ). This result suggests that the bounded $\mathrm{CH}_{3} \cdot$ prefers to react with another gas-phase $\mathrm{CH}_{3} \cdot$ to form $\mathrm{C}_{2} \mathrm{H}_{6}$ rather than to desorb into the gas phase. Theoretically, if the whole reaction (adsorption and coupling) proceeds continuously and does not cool down at local minimum (LM), the TS with negative relative energy is not a significant reaction barrier [47]. It endows $\left(\mathrm{WO}_{3}\right)_{8}$ with $\mathrm{CH}_{3}$. coupling property. As the $\mathrm{CH}_{3}$. concentration on the surface of $\left(\mathrm{WO}_{3}\right)_{8}$ is very high (due to the strong $\mathrm{CH}_{3}$. affinity), the conversion of $\mathrm{CH}_{3}$. adsorbed on $\left(\mathrm{WO}_{3}\right)_{8}$ will make major contribution to the $\mathrm{C}_{2}$ productivity. In specific, when $\mathrm{CH}_{3}$. radicals are adsorbed on $\mathrm{Na}_{2} \mathrm{WO}_{4}$, the total electronic energy (that is, DFT calculated energy) decreases. The residual energy is converted to thermal energy such as molecular vibration. If molecular vibration is localized at the coupling site, and not dispersed. Such a vibrational energy can be reused to climb up the succeeding reaction barrier. The real situation is likely between the two ideal situations. (1) The vibrational energy can be completely (100\%) reused, or (2) not be reused ( $0 \%$ ) at all (i.e., adsorbed methyl radicals are cooled down in each LM). We don't know how
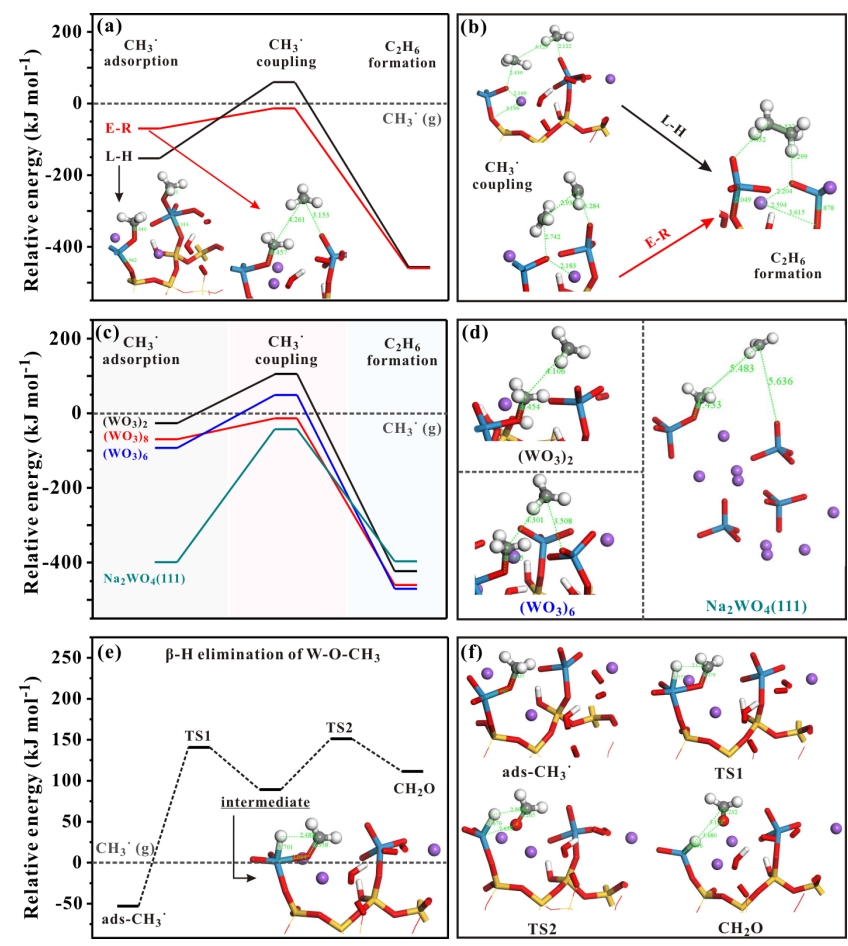

Fig. 3. DFT calculations for $\mathrm{CH}_{3}$. coupling over various catalyst models. (a) The energy profiles; (b) the corresponding configurations for $\mathrm{CH}_{3}$. coupling over $\left(\mathrm{WO}_{3}\right)_{8}$ via L-H mechanism and E-R mechanisms; (c) The energy profiles for $\mathrm{CH}_{3} \cdot$ coupling; (d) the configurations for $\mathrm{CH}_{3}{ }^{*}$ adsorption over various catalyst models. Other configurations are shown in Fig. S9. (e) The energy profile and (f) the corresponding configurations for the $\beta-\mathrm{H}$ elimination of $\mathrm{W}-\mathrm{O}-\mathrm{CH}_{3}$ over $\left(\mathrm{WO}_{3}\right)_{8}$. Yellow: $\mathrm{Si}$, red: $\mathrm{O}$, blue: $\mathrm{W}$, purple: $\mathrm{Na}$, gray: $\mathrm{C}$, and white: $\mathrm{H}$. $\left(\mathrm{WO}_{3}\right)_{2},\left(\mathrm{WO}_{3}\right)_{6}$, and $\left(\mathrm{WO}_{3}\right)_{8}$ abbreviate $\quad \mathrm{Si}_{48} \mathrm{O}_{112} \mathrm{H}_{30} \mathrm{Na}_{2}\left(\mathrm{WO}_{3}\right)_{2}, \quad \mathrm{Si}_{48} \mathrm{O}_{112} \mathrm{H}_{26} \mathrm{Na}_{6}\left(\mathrm{WO}_{3}\right)_{6}, \quad$ and $\left[\mathrm{Si}_{12} \mathrm{O}_{28} \mathrm{H}_{6} \mathrm{Na}_{2}\left(\mathrm{WO}_{3}\right)_{2}\right]_{4}$, respectively. 
much degree the thermal energy is maintained and can be reused, but the agreement with experimental results justifies this interpretation. Besides, we also calculated the $\beta$-H elimination of $\mathrm{W}-\mathrm{O}-\mathrm{CH}_{3}$ to produce formaldehyde (an important intermediate to generate $\left.\mathrm{CO}_{x}\right)$ over $\left(\mathrm{WO}_{3}\right)_{8}$. As shown in Figs. 3(e,f), the $\beta-\mathrm{H}$ elimination of $\mathrm{W}-\mathrm{O}-\mathrm{CH}_{3}$ has a large reaction barrier $(194 \mathrm{~kJ}$ $\mathrm{mol}^{-1}$ ) and an endothermic reaction energy of $164 \mathrm{~kJ} \mathrm{~mol}^{-1}$. It is therefore thermodynamically unfavorable as compared to its coupling with gas-phase $\mathrm{CH}_{3}$ radical to produce $\mathrm{C}_{2} \mathrm{H}_{6}$. Taking all these results together, the major role of $5 \mathrm{NaWSi}$ is not to improve the efficiency of $\mathrm{CH}_{3}$. coupling, but change the relative $\mathrm{CH}_{3}$. concentration on surface and in gas-phase, which make surface coupling a major pathway for $\mathrm{C}_{2}$ production and minimize undesired gas-phase side reactions (e.g. $\mathrm{CH}_{3}{ }^{\bullet}+\mathrm{O}_{2}$ reaction).

In principle, a good coupling catalyst requires not only the ability to combine two radicals to produce ethane, but also to inhibit the over-oxidation of ethane and ethylene. To test this hypothesis, we conducted the oxidation of ethane and ethylene on various catalysts. As shown in Figs. 2(e,f), against the good catalytic performance of $\mathrm{La}_{2} \mathrm{O}_{3}, 5 \mathrm{NaWSi}$ is inert for ethylene and ethane oxidation at temperatures below $700{ }^{\circ} \mathrm{C}$. The $T_{50}$ (ignition temperature, a temperature at $50 \%$ conversion of ethane/ethylene) of $5 \mathrm{NaWSi}$ is even higher than the blank control. More importantly, by mixing with $5 \mathrm{NaWSi}$, the oxidation of ethylene and ethane on $\mathrm{La}_{2} \mathrm{O}_{3}$ is significantly suppressed. Recently, advanced reactor concepts including chemical looping $[48,49]$ and membrane reactor $[50,51]$ have showed improved $\mathrm{C}_{2}$ production performance for OCM reaction. In these reactors, the gas phase deep oxidations were minimized by separating gas phase oxygen from carbon-containing stream. Similar concept also applies to this study. The selective coupling of methyl radicals on the catalyst surface spatially separates methyl radicals and $\mathrm{C}_{2}$ species from gas phase oxygen and therefore significantly suppresses the overoxidation. It is important to highlight that $\mathrm{La}_{2} \mathrm{O}_{3}-5 \mathrm{NaWSi}$ can effectively catalyze OCM at a temperature $\left(10.9 \% \mathrm{C}_{2}\right.$ yield at $\left.570{ }^{\circ} \mathrm{C}\right)$ below the corresponding ignition temperature of $\mathrm{C}_{2} \mathrm{H}_{4}$ and $\mathrm{C}_{2} \mathrm{H}_{6}\left(\sim 600{ }^{\circ} \mathrm{C}\right.$, Figs. 2(e,f)). It is therefore more controllable, possibly safer, and certainly more attractive as an actual process.

\section{3. $\quad$ 5NaWSi coupled with other metal oxides}

Based on the knowledge of surface coupling over $5 \mathrm{NaWSi}$, we then investigated the OCM performance of transition metal oxides-5NaWSi composite catalysts. As shown in Fig. 4, $\mathrm{Cr}_{2} \mathrm{O}_{3}$, $\mathrm{MnO}_{2}, \mathrm{Fe}_{2} \mathrm{O}_{3}$ and $\mathrm{Co}_{3} \mathrm{O}_{4}$ are typical methane-combustion catalysts which have very limited catalytic activity towards OCM at $755^{\circ} \mathrm{C}$. Surprisingly, when these metal oxides are physically mixed with $5 \mathrm{NaWSi}$, the $\mathrm{C}_{2}$ yield is improved by 5-14 times though the $\mathrm{CH}_{4}$ conversion remains unchanged. Specifically, $\mathrm{Fe}_{2} \mathrm{O}_{3}-5 \mathrm{NaWSi}$ shows a $\mathrm{C}_{2}$ yield of 0.92 whereas $\mathrm{Fe}_{2} \mathrm{O}_{3}$ shows zero $\mathrm{C}_{2}$ yield. $\mathrm{Co}_{3} \mathrm{O}_{4}-5 \mathrm{NaWSi}$ achieves a $\mathrm{C}_{2}$ yield of 3.73 , which is ca. 14 times as high as that of pure $\mathrm{Co}_{3} \mathrm{O}_{4}$. The constant $\mathrm{CH}_{4}$ conversion and unprecedentedly improved $\mathrm{C}_{2}$ yield suggest that $5 \mathrm{NaWSi}$ can even couple $\mathrm{CH}_{3}$. radicals generated by methane-combustion catalysts to produce $\mathrm{C}_{2}$ species. The en-

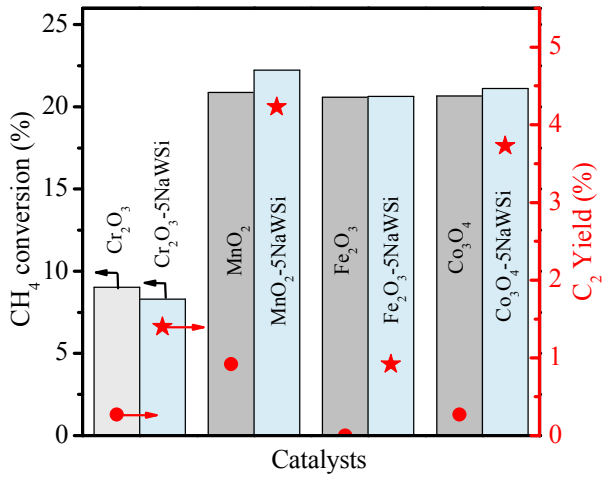

Fig. 4. Catalytic performance of transition metal oxides and their mixture with $5 \mathrm{NaWSi}$ at $755 \pm 15^{\circ} \mathrm{C}$ for $\mathrm{OCM}$ reaction. $\mathrm{CH}_{4}: \mathrm{O}_{2}: \mathrm{N}_{2}=3: 1: 2.6$, total gas flow rate $66 \mathrm{~mL} \mathrm{~min}^{-1}$.

dowed OCM activity by $5 \mathrm{NaWSi}$ catalyst further confirms its important role in methyl radical transformation, which suggests a new strategy to explore efficient OCM catalyst operated at low reaction temperature.

\section{Conclusions}

In summary, we have developed a bifunctional OCM catalyst system that can activate $\mathrm{CH}_{4}$ and selectively couple $\mathrm{CH}_{3} \cdot$ radicals over two separated catalysts. A $\mathrm{C}_{2}$ yield as high as $10.9 \%$ is achieved at a temperature $\left(570{ }^{\circ} \mathrm{C}\right)$ below the ignition temperature of $\mathrm{C}_{2} \mathrm{H}_{4}$ and $\mathrm{C}_{2} \mathrm{H}_{6}$. Similar to the bifunctional catalysis in Mo catalyzed methane dehydroaromatization [6,52,53], a tight control over both of the functional components is also of great importance to the OCM reaction. Future work will focus on the exploration of advanced catalysts that can either generate $\mathrm{CH}_{3}$. radicals more efficiently or couple $\mathrm{CH}_{3}{ }^{\bullet}$ radicals more selectively on the surface.

\section{Electronic supporting information}

Supporting information is available in the online version of this article.

\section{References}

[1] E. McFarland, Science, 2012, 338, 340-342.

[2] N. Agarwal, S. J. Freakley, R. U. McVicker, S. M. Althahban, N. Dimitratos, Q. He, D. J. Morgan, R. L. Jenkins, D. J. Willock, S. H. Taylor, C. J. Kiely, G. J. Hutchings, Science, 2017, 358, 223-227.

[3] Y. Amenomiya, V. I. Birss, M. Goledzinowski, J. Galuszka, A. R. Sanger, Catal. Rev. Sci. Eng., 1990, 32, 163-227.

[4] J. H. Lunsford, Angew. Chem. Int. Ed., 1995, 34, 970-980.

[5] P. Wang, G. Zhao, Y. Wang, Y. Lu, Sci. Adv., 2017, 3, e1603180.

[6] J. Gao, Y. Zheng, J.-M. Jehng, Y. Tang, I. E. Wachs, S. G. Podkolzin, Science, 2015, 348, 686-690.

[7] X. Guo, G. Fang, G. Li, H. Ma, H. Fan, L. Yu, C. Ma, X. Wu, D. Deng, M. Wei, D. Tan, R. Si, S. Zhang, J. Li, L. Sun, Z. Tang, X. Pan, X. Bao, Science, 2014, 344, 616-619.

[8] K. Cheng, B. Gu, X. Liu, J. Kang, Q. Zhang, Y. Wang, Angew. Chem. Int. Ed., 2016, 55, 4725-4728.

[9] F. Jiao, J. Li, X. Pan, J. Xiao, H. Li, H. Ma, M. Wei, Y. Pan, Z. Zhou, M. Li, 


\section{Graphical Abstract}

\section{Chin. J. Catal., 2021, 42: 1117-1125 doi: 10.1016/S1872-2067(20)63756-1}

\section{Surface coupling of methyl radicals for efficient low-temperature oxidative coupling of methane}

Shihui Zou*, Zhinian Li, Qiuyue Zhou, Yang Pan, Wentao Yuan, Lei He, Shenliang Wang, Wu Wen, Juanjuan Liu, Yong Wang, Yonghua Du, Jiuzhong Yang, Liping Xiao, Hisayoshi Kobayashi*, Jie Fan*

Zhejiang University, China; University of Science and Technology of China, China; Hangzhou Dianzi University, China; Brookhaven National Laboratory, USA; Kyoto Institute of Technology, Japan

Methyl radicals generated by $\mathrm{La}_{2} \mathrm{O}_{3}$ can selectively couple on the surface of $5 \mathrm{wt} \%$ $\mathrm{Na}_{2} \mathrm{WO}_{4} / \mathrm{SiO}_{2}$. The controllable surface coupling against overoxidation barely changes the activity of $\mathrm{La}_{2} \mathrm{O}_{3}$ but boosts the $\mathrm{C}_{2}$ selectivity by three times and achieves a $\mathrm{C}_{2}$ yield as high as $10.9 \%$ at bed temperature of only $570{ }^{\circ} \mathrm{C}$.

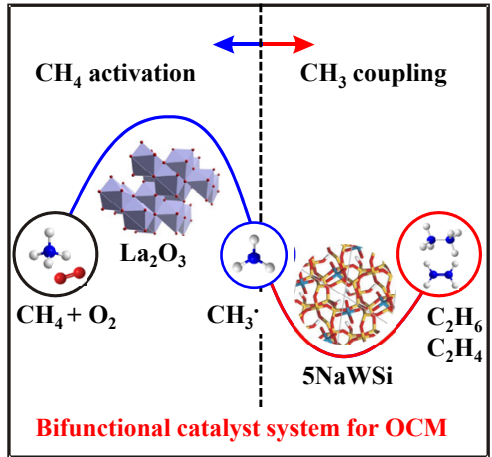

S. Miao, J. Li, Y. Zhu, D. Xiao, T. He, J. Yang, F. Qi, Q. Fu, X. Bao, Science, 2016, 351, 1065-1068.

[10] L. Zhong, F. Yu, Y. An, Y. Zhao, Y. Sun, Z. Li, T. Lin, Y. Lin, X. Qi, Y. Dai, L. Gu, J. Hu, S. Jin, Q. Shen, H. Wang, Nature, 2016, 538, 84.

[11] H. M. Torres Galvis, J. H. Bitter, C. B. Khare, M. Ruitenbeek, A. I. Dugulan, K. P. de Jong, Science, 2012, 335, 835-838.

[12] P. Zhai, C. Xu, R. Gao, X. Liu, M. Li, W. Li, X. Fu, C. Jia, J. Xie, M. Zhao, X. Wang, Y.-W. Li, Q. Zhang, X.-D. Wen, D. Ma, Angew. Chem. Int. Ed., 2016, 55, 9902-9907.

[13] C. Hammond, S. Conrad, I. Hermans, ChemSusChem, 2012, 5, 1668-1686.

[14] V. S. Arutyunov, L. N. Strekova, J. Mol. Catal. A, 2017, 426, 326-342.

[15] Z. Li, L. He, S. Wang, W. Yi, S. Zou, L. Xiao, J. Fan, ACS Comb. Sci,, 2017, 19, 15-24.

[16] Z. Li, S. Wang, W. Hong, S. Zou, L. Xiao, J. Fan, ChemNanoMat, 2018, 4, 487-495.

[17] A. Galadima, O. Muraza, J. Ind. Eng. Chem., 2016, 37, 1-13.

[18] G. E. Keller, M. M. Bhasin, J. Catal., 1982, 73, 9-19.

[19] U. Zavyalova, M. Holena, R. Schlögl, M. Baerns, ChemCatChem, 2011, 3, 1935-1947.

[20] Z. Liu, J. P. Ho Li, E. Vovk, Y. Zhu, S. Li, S. Wang, A. P. van Bavel, Y. Yang, ACS Catal., 2018, 8, 11761-11772.

[21] M. J. Gradassi, N. Wayne Green, Fuel Proc. Technol., 1995, 42, 65-83.

[22] D. J. Driscoll, W. Martir, J. X. Wang, J. H. Lunsford, J. Am. Chem. Soc., 1985, 107, 58-63.

[23] B. Beck, V. Fleischer, S. Arndt, M. G. Hevia, A. Urakawa, P. Hugo, R. Schomäcker, Catal. Today, 2014, 228, 212-218.

[24] V. S. Arutyunov, V. Y. Basevich, V. I. Vedeneev, O. V. Krylov, Kinet. Catal., 1999, 40, 382-387.

[25] Y. S. Su, J. Y. Ying, W. H. Green, J. Catal., 2003, 218, 321-333.

[26] P. Huang, Y. Zhao, J. Zhang, Y. Zhu, Y. Sun, Nanoscale, 2013, 5, 10844-10848.

[27] J. Xu, L. Peng, X. Fang, Z. Fu, W. Liu, X. Xu, H. Peng, R. Zheng, X. Wang, Appl. Catal. A, 2018, 552, 117-128.

[28] C. Mesters, Annu. Rev. Chem. Biomol. Eng., 2016, 7, 223-238.

[29] H. Chen, J. Niu, B. Zhang, S. Li, Chin. J. Catal, 2000, 21, 55-58.

[30] Z. Zhou, X. Du, J. Yang, Y. Wang, C. Li, S. Wei, L. Du, Y. Li, F. Qi, Q. Wang, J. Synchrotron Radiat., 2016, 23, 1035-1045.

[31] V. Milman, B. Winkler, J. A. White, C. J. Pickard, M. C. Payne, E. V. Akhmatskaya, R. H. Nobes, Int. J. Qunatum Chem., 2000, 77,
895-910.

[32] M. C. Payne, M. P. Teter, D. C. Allan, T. A. Arias, J. D. Joannopoulos, Rev. Mod. Phys., 1992, 64, 1045-1097.

[33] J. P. Perdew, K. Burke, M. Ernzerhof, Phys. Rev. Lett., 1996, 77, 3865-3868.

[34] K. Laasonen, R. Car, C. Lee, D. Vanderbilt, Phys. Rev. B, 1991, 43, 6796-6799.

[35] F. R. Zurcher, E. C. Scher, J. M. Cizeron, W. P. Schammel, A. Tkachenko, J. Gamoras, D. Karshtedt, N. Greg, A. Rumplecker, J. McCormick, US Patent 8962517, 2015.

[36] M. S. Palmer, M. Neurock, M. M. Olken, J. Am. Chem. Soc., 2002, 124 8452-8461.

[37] L. Luo, X. Tang, W. Wang, Y. Wang, S. Sun, F. Qi, W. Huang, Sci. Rep., 2013, 3, 1625.

[38] L. Luo, R. You, Y. Liu, J. Yang, Y. Zhu, W. Wen, Y. Pan, F. Qi, W. Huang, ACS Catal., 2019, 9, 2514-2520.

[39] B. Fu, T. Jiang, Y. Zhu, J. Nanosci. Nanotechnol., 2018, 18, 3398-3404.

[40] S. Arndt, T. Otremba, U. Simon, M. Yildiz, H. Schubert, R. Schomäcker, Appl. Catal. A, 2012, 425-426, 53-61.

[41] A. Palermo, J. P. Holgado Vazquez, A. F. Lee, M. S. Tikhov, R. M. Lambert, J. Catal., 1998, 177, 259-266.

[42] S. Ji, T. Xiao, S. Li, L. Chou, B. Zhang, C. Xu, R. Hou, A. P. E. York, M. L. H. Green, J. Catal., 2003, 220, 47-56.

[43] Z. C. Jiang, C. J. Yu, X. P. Fang, S. B. Li, H. L. Wang, J. Phys. Chem., 1993, 97, 12870-12875.

[44] S. Yamazoe, Y. Hitomi, T. Shishido, T. Tanaka, J. Phys. Chem. $C$ 2008, 112, 6869-6879.

[45] H.-S. Chen, J.-Z. Niu, B. Zhang, S.-B. Li, Acta Phys. Chim. Sin., 2001, $17,111-115$

[46] A. J. Medford, A. Vojvodic, J. S. Hummelshøj, J. Voss, F. Abild-Pedersen, F. Studt, T. Bligaard, A. Nilsson, J. K. Nørskov, J. Catal., 2015, 328, 36-42.

[47] Z.-C. Wang, W. Xue, Y.-P. Ma, X.-L. Ding, S.-G. He, F. Dong, S. Heinbuch, J. J. Rocca, E. R. Bernstein, J. Phys. Chem. A, 2008, 112, 5984-5993.

[48] V. Fleischer, U. Simon, S. Parishan, M. G. Colmenares, O. Görke, A. Gurlo, W. Riedel, L. Thum, J. Schmidt, T. Risse, K.-P. Dinse, R. Schomäcker, J. Catal., 2018, 360, 102-117.

[49] S. Parishan, P. Littlewood, A. Arinchtein, V. Fleischer, R. Schomäcker, Catal. Today, 2018, 311, 40-47. 
[50] V. O. Igenegbai, R. J. Meyer, S. Linic, Appl. Catal. B, 2018, 230, 29-35.

[51] V. O. Igenegbai, R. Almallahi, R. J. Meyer, S. Linic, ACS Energy Lett., 2019, 4, 1465-1470.
[52] J. Gao, Y. Zheng, G. B. Fitzgerald, J. de Joannis, Y. Tang, I. E. Wachs, S. G. Podkolzin, J. Phys. Chem. C, 2014, 118, 4670-4679.

[53] Y. Zheng, Y. Tang, J. R. Gallagher, J. Gao, J. T. Miller, I. E. Wachs, S. G. Podkolzin, J. Phys. Chem. C, 2019, 123, 22281-22292.

\title{
表面偶联甲基自由基实现低温高效甲烷氧化偶联
}

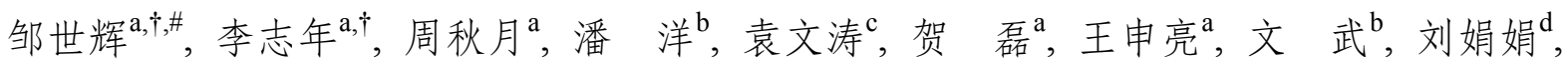

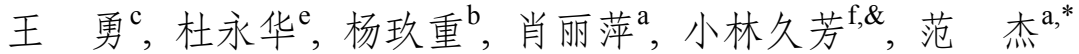 \\ a浙江大学化学系浙江省应用化学重点实验室, 浙江杭州 310027 , 中国 \\ ${ }^{b}$ 中国科学技术大学, 国家同步辐射重点实验室, 安徽合肥 230029 , 中国 \\ c 浙江大学材料科学与工程学院, 浙江杭州 310027 , 中国 \\ d 杭州电子大学, 材料与环境工程学院, 浙江杭州 310036 , 中国 \\ e布鲁克海文国家实验室，国家同步辐射光源II，纽约11973，美国

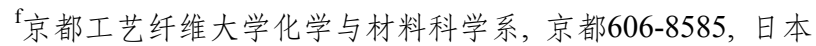

摘要: 天然气作为一种低碳清洁能源, 其储量大, 价格低, 被认为是最有前途的石油替代资源之一. 而以天然气的主要成分 甲烷为原料来生产高价值化学品被认为是石化工业中实现天然气取代石油为原料新化工路线的技术基础, 具有极为 可观的社会经济价值. 目前甲烷的化学利用主要采用间接转化法, 即先从甲烷制合成气, 再由合成气制备各种化工原料和 油品. 但该路线流程复杂, 能耗大, 生产成本高及投资大, 具有明显的局限性, 这促使着人们不断探索能量效率更高的甲烷 直接转化技术.

甲烷氧化偶联 $(\mathrm{OCM})$ 是最重要的甲烷直接转化技术之一. 自1 1982 首次报道以来, 人们开发了 1000 多种OCM催化剂, 涉 及元素超过 68 种, 但 $\mathrm{C}_{2}$ 烃类(乙烷和乙烯)的收率普遍低于 $30 \%$, 尚未实现工业化. 传统研究认为, OCM反应遵循“多相-均 相”催化反应机理, 甲烷在催化剂表面活化产生甲基自由基后, 在气相中进行偶联生成乙烷和乙烯等产物. 由于高温下甲基 自由基很容易脱附到气相, 传统的 $\mathrm{OCM}$ 催化剂一般只在甲基自由基的产生这一步发挥作用. 而随后在气相中发生的甲基 自由基均相反应并不受催化剂控制, 在热力学驱动下, 会倾向于深度氧化生成 $\mathrm{CO}_{2}$ 等副产物, 因此OCM反应中 $\mathrm{C}_{2}$ 的收率上 限为 $25 \%-28 \%$. 理论上来说, 只有当催化剂能够在甲基自由基偶联这一步发挥作用时, $\mathrm{C}_{2}$ 物种的收率才可能打破上限, 但 目前尚未有催化剂实现甲基自由基可控表面偶联.

本文提出并证实 $5 \mathrm{wt} \% \mathrm{Na}_{2} \mathrm{WO}_{4} / \mathrm{SiO}_{2}(5 \mathrm{NaWSi})$ 具有催化甲基自由基表面偶联的能力. 在低温下, $5 \mathrm{NaWSi}$ 本身对于 $\mathrm{OCM}$ 没有催化活性, 但是它的加入能够显著提高 $\mathrm{La}_{2} \mathrm{O}_{3}$ 催化剂的 $\mathrm{C}_{2}$ 选择性, 进而提高 $\mathrm{C}_{2}$ 收率, 使其在 $570{ }^{\circ} \mathrm{C}$ 的低温下即可达 到 $10.9 \%$ 的 $\mathrm{C}_{2}$ 收率. 在 $\mathrm{La}_{2} \mathrm{O}_{3}$ 和 $5 \mathrm{NaWSi}$ 之间加入一层甲基自由基淬灭剂——石英砂, 这种提升作用随即消失, 表明甲基自由 基在 $5 \mathrm{NaWSi}$ 上的表面偶联可能是 $\mathrm{C}_{2}$ 选择性和收率提升的主要原因. 本文进一步采用同步辐射光电离质谱技术原位检测了 反应过程中的自由基中间体, 结果发现, $\mathrm{La}_{2} \mathrm{O}_{3}$ 表面产生的甲基自由基确实可以在 $5 \mathrm{NaWSi}$ 表面进行偶联, 进而提高 $\mathrm{C}_{2}$ 的选 择性和收率. 通过对 $5 \mathrm{NaWSi}$ 的组成和结构进行分析, 发现 $5 \mathrm{NaWSi}$ 中的 $\mathrm{Na}_{2} \mathrm{WO}_{4}$ 纳米团簇可能是甲基自由基偶联的活性位 点, 该位点不仅具有很强的甲基自由基吸附能力, 为甲基自由基表面偶联提供机会, 同时不会深度氧化 $\mathrm{C}_{2}$ 物种, 有效地提高 $了 \mathrm{C}_{2}$ 选择性. 以此为基础建立理论模型, 我们通过DFT计算对甲基自由基在 $5 \mathrm{NaWSi}$ 表面的偶联机制进行了研究. 结果表 明, $5 \mathrm{NaWSi}$ 对甲基自由基具有很强的吸附能力, 而吸附后的甲基自由基更倾向于偶联生成 $\mathrm{C}_{2}$ 产物, 而不是 $\beta$ - $\mathrm{H}$ 消除生成 $\mathrm{HCHO}$ 等副产物, 表明 $5 \mathrm{NaWSi}$ 确实是很好的甲基自由基表面偶联催化剂. 甲基自由基表面偶联的证实为 $\mathrm{OCM}$ 催化剂的开 发开辟了新方向. 从双功能催化剂设计的角度出发, 将OCM反应分解成甲烷活化和甲基自由基偶联这两个部分, 并分别针 对这两个部分来篮选和优化催化剂, 将有望突破 $\mathrm{C}_{2}$ 收率上限, 进而推进 $\mathrm{OCM}$ 的工业化进程.

关键词: 甲烷氧化偶联; 双功能催化; 甲基自由基; 表面偶联; $\mathrm{La}_{2} \mathrm{O}_{3} ; \mathrm{Na}_{2} \mathrm{WO}_{4} / \mathrm{SiO}_{2}$

收稿日期: 2021-01-04. 接受日期: 2021-01-09. 上网时间: 2021-03-05.

*通讯联系人. 电话/传真: (0571)87952338; 电子信箱: jfan@zju.edu.cn

通讯联系人. 电子信箱: xueshan199@163.com

\&通讯联系人. 电子信箱: hisabbit@yahoo.co.jp

†共同第一作者.

基金来源：国家自然科学基金(92045301，91845203，21802122，21703050); 中国科学院合肥大科学中心重点研发项目 (2018HSC-KPRD002).

本文的电子版全文由Elsevier出版社在ScienceDirect上出版(http://www.sciencedirect.com/journal/chinese-journal-of-catalysis). 